\title{
TOTAL NONDIALYZABLE SOLIDS (TNDS) IN HUMAN URINE. IX. IMMUNOCHEMICAL STUDIES OF THE R-1 "UROMUCOID" FRACTION *
}

\author{
By WILLIAM H. BOYCE, J. STANTON KING, JR.† AND MARVEL L. FIELDEN \\ (From the Departments of Urology and Biochemistry, The Bowman Gray School of Medicine
}

of Wake Forest College, Winston-Salem, N. C.)

(Submitted for publication January 12, 1961; accepted April 27, 1961)

A method has been described for separation of the nondialyzable solids of normal urine into three major fractions (1). The R-1 fraction is composed of the portion which is not filtrable through collodion membranes of average pore diameter 20 $\mathrm{m} \mu$, and which is insoluble in veronal buffer of $\mathrm{pH} 8.6$ and ionic strength 0.1 . A mean excretion rate of $90 \mathrm{mg}$ per 24 hours (range, 51 to $168 \mathrm{mg}$ per 24 hours) has been established for both male and female adults. Attempts to separate the R-1 into subfractions by electrophoresis, various solvents, and ultracentrifugation have failed to provide subfractions which were distinctly different in composition from the original material. The present paper reports a further characterization of the R-1 mucosubstance by immunological methods.

\section{MATERIALS AND METHODS}

The R-1 fraction of normal human urine was recovered, as previously described $(1,2)$, by veronal buffer ( $\mathrm{pH} 8.6$, ionic strength 0.1 ) extraction of the nonultrafiltrable solids of dialyzed urine. The fraction was suspended in distilled water and centrifuged at 40,000 $\mathrm{G}$ for 30 minutes, leaving a supernatant colorless opalescent gel or solution, or both, of approximately $5 \mathrm{mg}$ per $\mathrm{ml}$, which was used in the following experiments. The analyses of the centrifugate and supernate are given in Table I; the brown pellet is composed at least partly of cellular detritus and some inorganic crystalline material. The supernatant colloid migrated electrophoretically as a single hypersharp peak of ascending mobility $9.6 \times 10^{-5} \mathrm{~cm}^{2} \cdot \mathrm{sec}^{-1} \cdot$ volt $^{-1}$ in veronal buffer of $\mathrm{pH}$ 8.18 and ionic strength 0.01 at a potential gradient of $5.8 \mathrm{v}$ per $\mathrm{cm}$. A frozen but unlyophilized sample of R-1 in water ( $5 \mathrm{mg}$ per $\mathrm{ml}$ ) was ultracentrifuged by $\mathrm{M}$. C. Davies, Lederle Laboratories. A single hypersharp

* Supported by Public Health Service Grant A-259, National Institutes of Health, and by grants from the John A. Hartford Foundation, the Mary Reynolds Babcock Foundation and the American Urological Research Foundation.

$\nmid$ Helen Hay Whitney Foundation Research Fellow. gradient of rapidly sedimenting material was present with a barely detectable trace of a slower moving component. Lyophilization increased the relative quantity of the slower component.

Freshly prepared unlyophilized material had an absorption maximum in the ultraviolet at $277 \mathrm{~m} \mu$, and solubility properties like those of the urinary mucoprotein of Tamm and Horsfall (3), including precipitability with cetyltrimethylammonium bromide (CTAB) (4). At least 96 per cent of the hexosamine emerged from a Gardell column (5) at the same effluent volume as glucosamine, the rest appearing at the same volume as galactosamine.

Preparation of antibodies. Aqueous suspensions of freshly prepared R-1 were mixed with an equal volume of Freund's complete adjuvant (Difco Laboratories); the final suspension contained $8 \mathrm{mg}$ of the antigen per $\mathrm{ml}$. This suspension was injected into the foot-pads of adult rabbits so that each animal received $64 \mu \mathrm{g}$ of antigen nitrogen in each of four feet. Injections were repeated at intervals of 1,3 and 6 weeks. Intravenous challenge was avoided, since it regularly resulted in anaphylactic death. There was significant antibody production at 10 days. The high titers of antibody obtained at 8 weeks have been maintained as long as 6 months without challenge. Six rabbits were used in each of four groups for antibody production. Serum was pooled and fractionated by the first steps of Cohn's method 10 (2). The entire antibody was found in the fraction corresponding to Cohn fractions I, II, III ( $\gamma$-globulins). The titers were sufficiently high that very satisfactory qualitative reaction, with the gel diffusion technique, was obtained with unfractionated rabbit antiserum. Antisera of identical

TABLE I

Analysis of lyophilized samples of supernatant gel and liquid phase after ultracentrifugation of a specimen of fraction $R-1$

\begin{tabular}{|c|c|c|c|c|c|c|}
\hline & \multirow[b]{2}{*}{ Hexosamine* } & \multicolumn{2}{|c|}{ Hexoset } & \multirow[b]{2}{*}{ Fucose } & \multirow{2}{*}{$\begin{array}{c}\text { Sialic } \\
\text { acid }\end{array}$} & \multirow[b]{2}{*}{$\mathbf{N}$} \\
\hline & & Anthrone & Orcinol & & & \\
\hline $\begin{array}{l}\text { Pelletł } \\
\text { Gel\& } \\
\text { Liquid\$ }\end{array}$ & $\begin{array}{l}2.9 \\
6.5 \\
6.9\end{array}$ & $\begin{array}{l}16.6 \\
14.4 \\
15.4\end{array}$ & $\begin{array}{l}8.7 \\
7.3 \\
7.3\end{array}$ & $\begin{array}{l}2.6 \\
1.5 \\
1.5\end{array}$ & $\begin{array}{l}<1 \\
<1 \\
<1\end{array}$ & $\begin{array}{l}7.45 \\
9.73 \\
9.84\end{array}$ \\
\hline
\end{tabular}

* As base.
† Standard: equal weights galactose and mannose. Figures include fucose.

$\$$ Approximately 25 per cent of fraction R-1 by dry weight. 
properties were produced in two rabbits by omitting the Freund's adjuvant, but required two to three times the above number of challenge doses.

Rabbit antihuman serum was prepared in a similar manner, using fresh human serum as the antigen.

Preparation of test antigens. The fractions of total nondialyzable solids of normal urine were prepared as previously described $(1,2)$. Samples of Tamm and Horsfall urinary mucoprotein (3), Di Ferrante-Rich mucosubstance (6), Maxfield mucoprotein (7) and AndersonMaclagan material (8) were prepared by the methods of the respective investigators.

Human renal tissue, removed by surgical biopsy of 8 kidneys requiring heminephrectomy (calculi or hydronephrosis), was frozen at $-18^{\circ} \mathrm{C}$. Twenty-four hours later the tissue was thawed and separated into bits of cortex, medulla, renal pelvis and transitional epithelium stripped from the renal pelvis. The samples were ground in sterile tissue grinders to prepare a slurry of approximately 1 part tissue to 5 parts distilled water. Biopsies of skin, subcutaneous fat, fascia and striated muscle from the abdominal wall were prepared in similar fashion. Virus hemagglutination-inhibitory mucoprotein of saliva was prepared by the method of Marmion, Curtain and Pye (9). Whole saliva was also utilized as antigen.

Erythrocyte membranes were prepared from fresh whole blood (disodium ethylenediamine tetraacetate anticoagulant). After centrifuging to separate the plasma, the erythrocytes were washed three times in 0.85 per cent saline and frozen at $-18^{\circ} \mathrm{C}$ for 24 hours. The erythrocytes were thawed and washed three times with 1 $\mathrm{M} \mathrm{NaCl}$ and the membranes recovered by ultracentrifugation at $10,000 \mathrm{G}$, solubilized by cold homogenization in

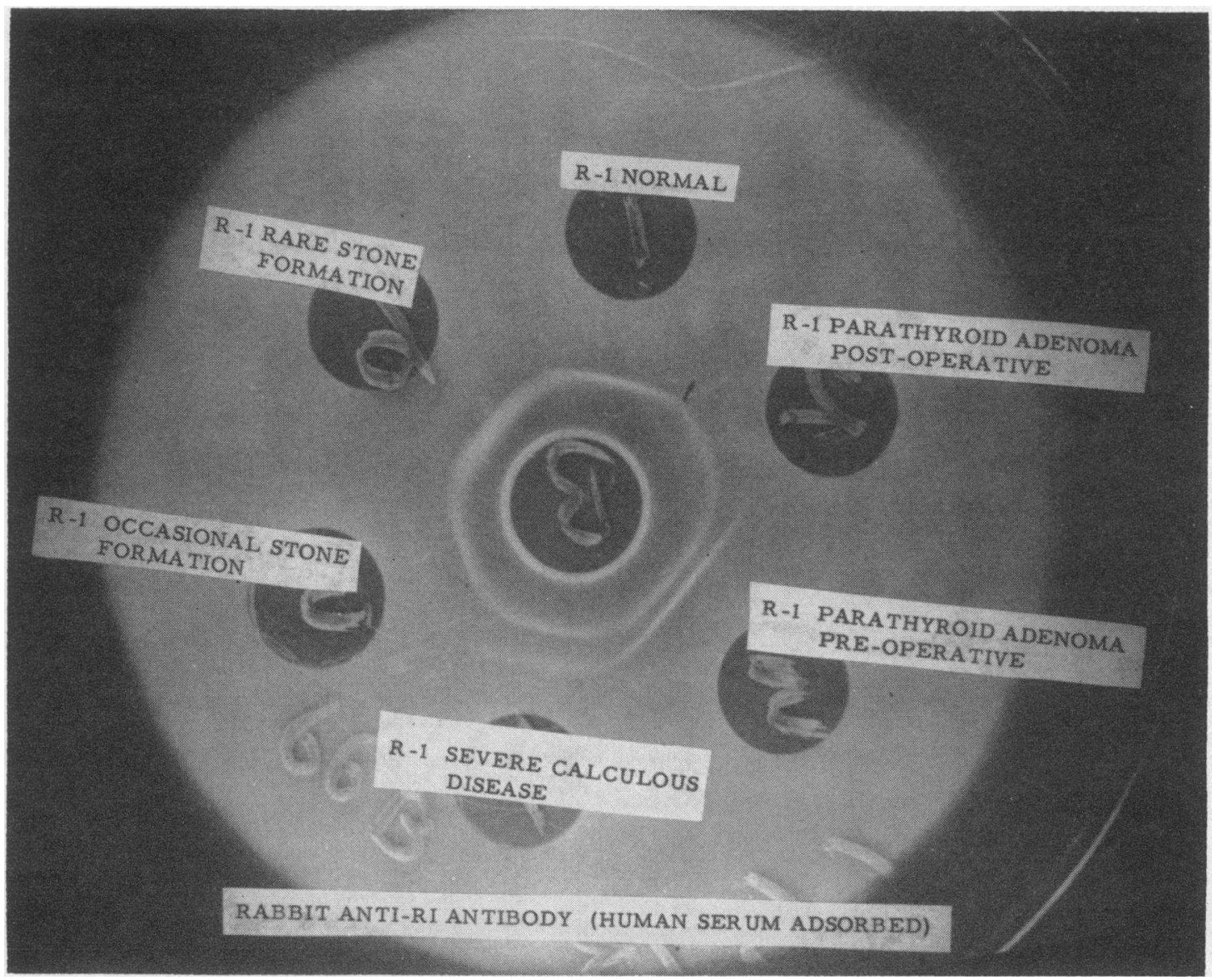

Fig. 1. Reaction of identity between R-1 mucoid From nORMal URine and from patients With RENAL CALCUli. Anti-R-1 antibody in center well contains $480 \mu \mathrm{g}$ of nitrogen, antigens in peripheral wells contain 60 to $80 \mu \mathrm{g}$ of nitrogen. The peripheral wells are numbered clockwise, with no. 1 at 12 o'clock. The significance of the two zones of precipitation in wells 3 and 4 is unknown. A patient with a single parathyroid adenoma and sterile urine had $127 \mathrm{mg}$ of R-1 per 24 hour urine volume preoperatively and $109 \mathrm{mg}$ between 48 and 72 hours after operation. The RS-1 excretion was $149 \mathrm{mg}$ per 24 hours preoperatively, of which $100 \mathrm{mg}$ had $\alpha_{1}$-globulin mobility at $\mathrm{pH} 8.6$. In the period 48 to 72 hours after operation, the RS-1 excretion was $33 \mathrm{mg}$ of which $3.7 \mathrm{mg}$ was $\alpha_{1}$ component. 


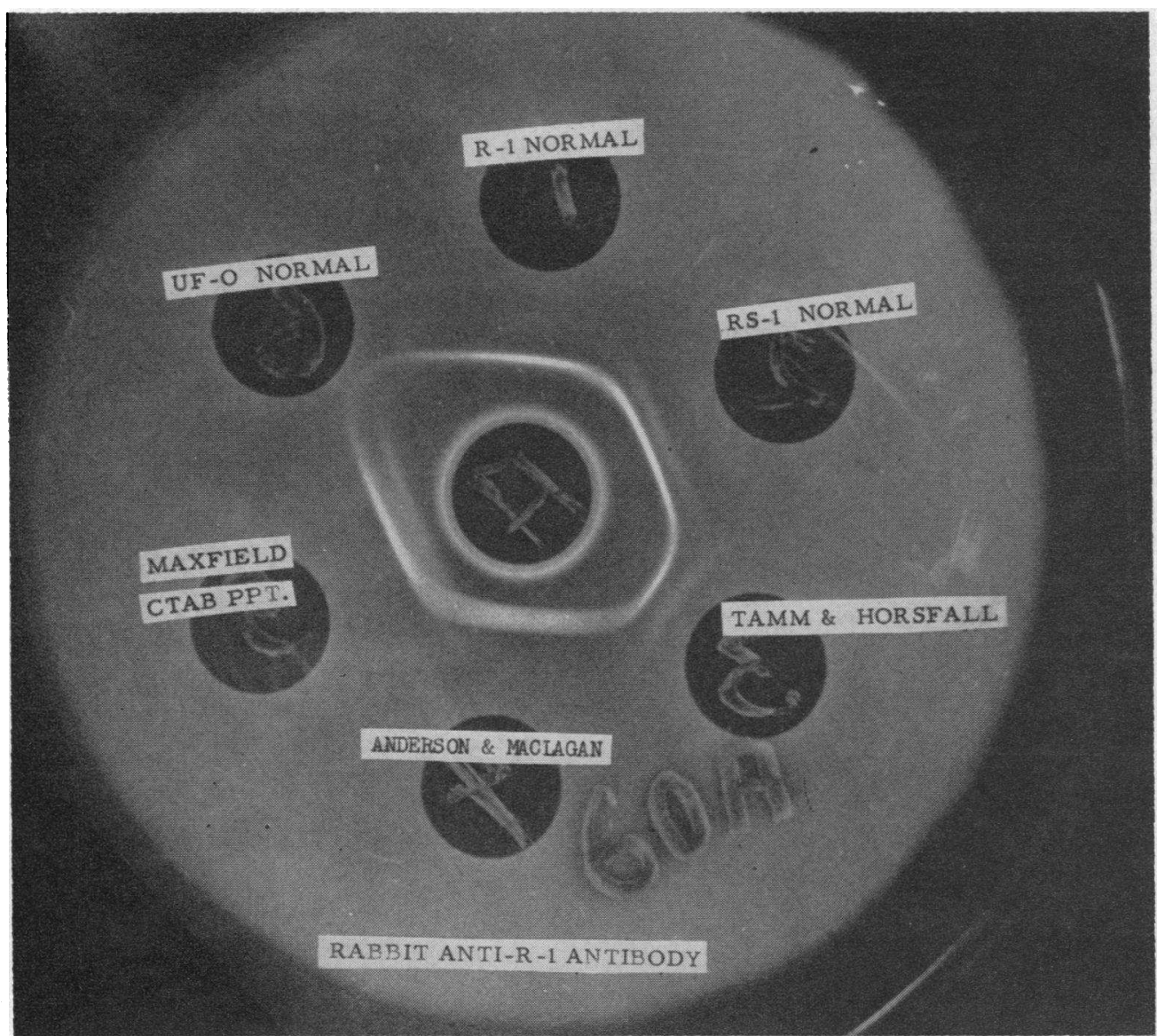

Fig. 2. Reaction of identity between R-1 and mucosubstances of NoRmal URine ReCOVERED BY VARIOUS TECHNIQUES. All test substances were lyophilized and each peripheral well contains approximately $1 \mathrm{mg}$ of dry weight in $0.4 \mathrm{ml}$ of distilled water. Freshly prepared unlyophilized preparations give similar precipitin reactions. The Tamm and Horsfall substance is the total precipitate from $0.58 \mathrm{M} \mathrm{NaCl}$-treated urine, and hence contains the portions soluble and insoluble in phosphate buffer. Two zones of precipitation commonly occur with this "crude" preparation. The UF-O does not give precipitin reactions with anti-R-1 antibody.

distilled water or by suspension in $0.17 \mathrm{M}$ urea, followed by dialysis against physiological saline to remove the urea. Samples of fresh and lyophilized R-1 were carried through all steps of this procedure without loss of the immune response to rabbit anti-R-1 antibody.

Immediately after removal, 22 calcigerous calculi were scrubbed with a sterile brush to remove surface debris and placed in cellophane bags in a 5 per cent solution of ethylenediamine tetraacetate, $\mathrm{pH}$ 7.8. Dialysis with mechanical agitation at $3^{\circ} \mathrm{C}$ removed the crystalline material in 5 to 12 days. The matrix remaining within the cellophane was dialyzed against distilled water and concentrated by suspending the cellophane containers in air currents at $3^{\circ} \mathrm{C}$ or by lyophilization. As a control, samples of freshly recovered R-1 were placed in cellophane bags and concomitantly carried through all steps of the preparation of the stone matrix. Preparations of whole bone matrix and collagen-free bone matrix were prepared as previously described (10).

Human plasma dilutions were made with physiological saline. Complement was removed by incubation at $56^{\circ} \mathrm{C}$ for 30 minutes and by storing at $3^{\circ} \mathrm{C}$ for 5 days. Concentrates of whole plasma proteins were prepared by dialyzing fresh plasma against distilled water and subsequent lyophilization. The dry proteins were taken up in physiological saline to give concentrations up to ten times those of normal serum. These lyophilized preparations retained their serological reactivity with rabbit antihuman serum protein antibody, giving six or more zones of precipitation in the gel diffusion tests.

Immunochemical methods. The technique for determination of the optimal proportions of antibody and antigen followed those of Dean and Webb (11). The technique of precipitation reactions in gels was that of Ouchterlony 
(12). Aseptic technique was maintained at all stages of the study.

\section{RESULTS}

Presence of $R-1$ in various fractions of urinary nondialyzable solids. Aqueous suspensions of R-1 antigen in concentrations of 0.05 to $10 \mathrm{mg}$ per $\mathrm{ml}$ gave a single distinct zone of precipitation in gel diffusion studies with the rabbit anti-R-1 antibody. This represents a range of approximately 20-fold from the optimal concentrations for serological reactivity as determined by the tube precipitation technique. A "reaction of identity" was obtained with R-1 from normal male and female subjects and from patients with renal calculi, pyelonephritis, Beck's sarcoidosis, multiple myeloma, and lupus erythematosus (Figure 1).

The antigenic reaction of $R-1$ to anti-R-1 antibody was well preserved after storage as a lyophilized powder for 5 years, dialysis against 10 per cent EDTA at $\mathrm{pH} 7.8$ for 2 weeks and against saturated urea for 1 hour, or heating at $100^{\circ} \mathrm{C}$ for 1 hour with $0.17 \mathrm{M}$ urea. Two zones of precipitation in gel were usually present in these various preparations of R-1. The more diffusible component invariably gave a reaction of identity with the freshly prepared R-1 antigen. The serological reactivity was still present in a solution of $\mathrm{R}-1$ made to $\mathrm{pH} 2.5$ with $\mathrm{HCl}$, allowed to stand 5 hours, then dialyzed against water. After adjustment to $\mathrm{pH} 11.7$ with $\mathrm{NaOH}$, standing and dialysis, the serological reactivity with rabbit antiR-1 antibody was not observed. Fresh human serum as a vehicle for suspensions of lyophilized R-1 ( $50 \mu \mathrm{g}$ to $5 \mathrm{mg}$ per $\mathrm{ml}$ ) did not interfere with the precipitin reactions of $\mathrm{R}-1$ to anti-R-1 antibody. Toluidine blue-O stained $\mathrm{R}-1$ orthochromatically, but did not interfere with the serological reactivity. The preparations of Tamm and Horsfall uri-

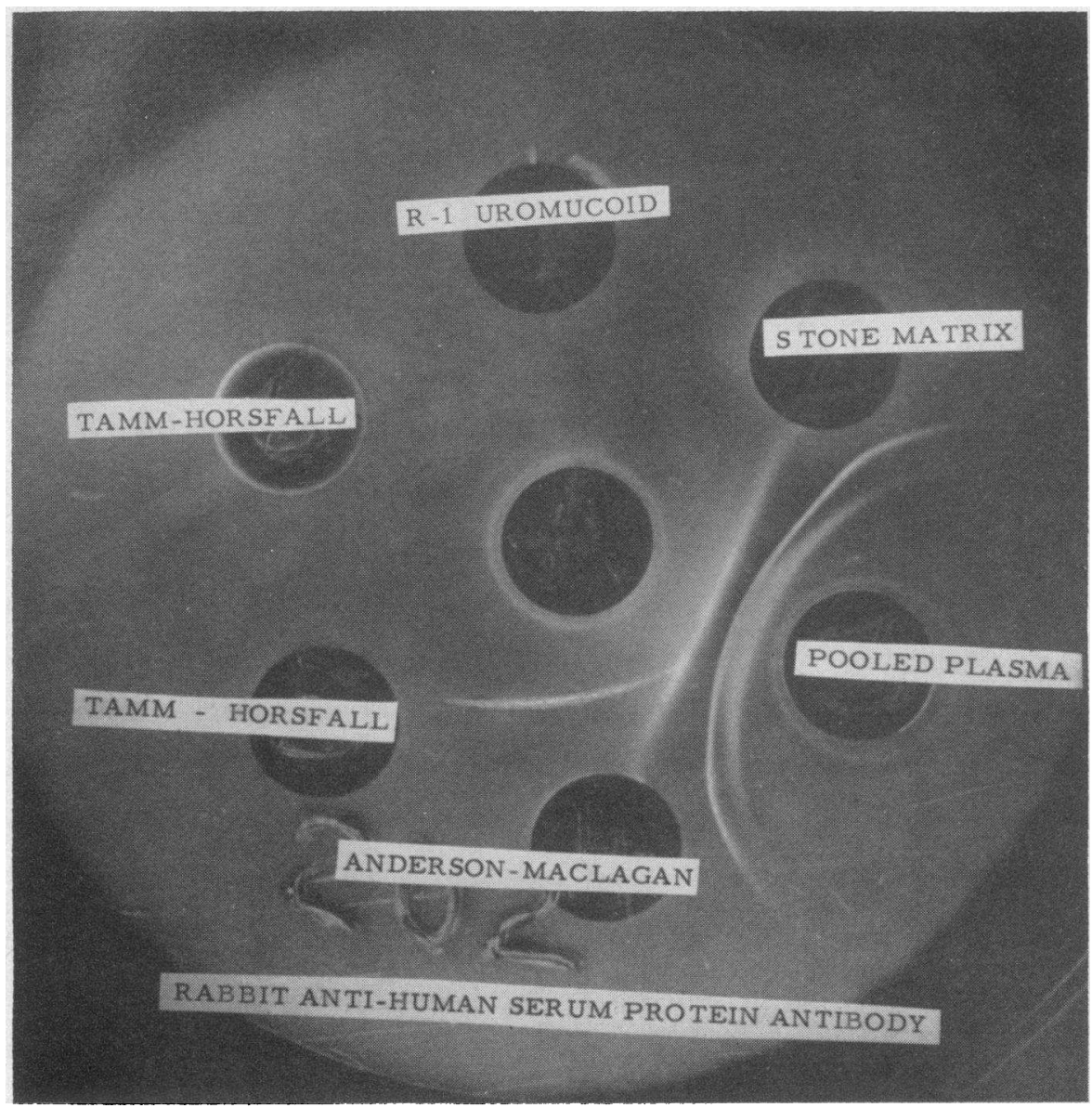

Fig. 3. Absence of precipitin reaction by R-1 and Tamm and Horsfall substances MATCHED WITH RABBIT ANTIHUMAN SERUM PROTEIN ANTIBODY. 


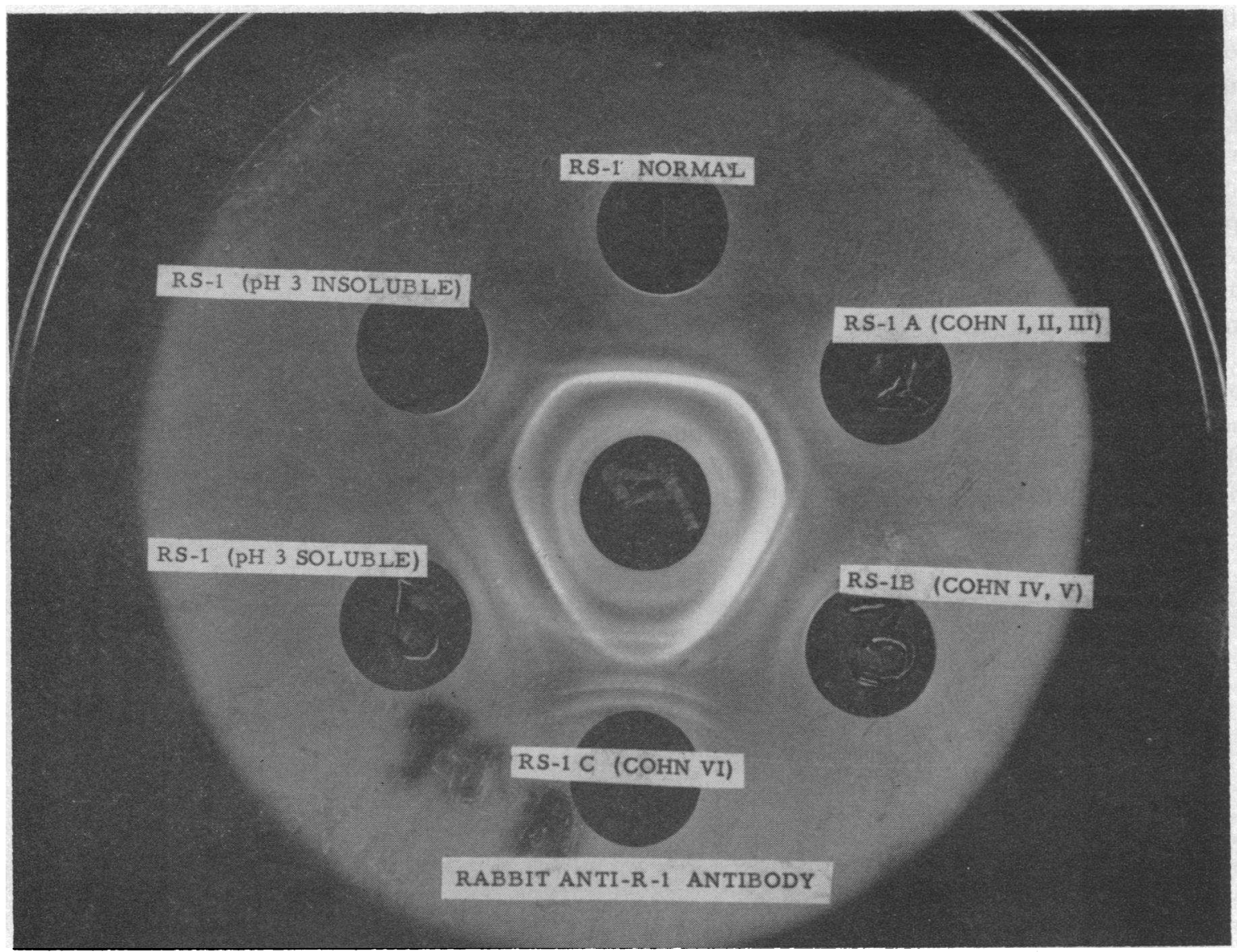

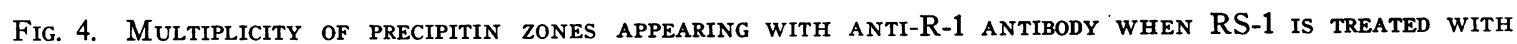
DILUTE ETHANOL, ZINC ACETATE AND DILUTE ACETIC ACID. The subfractions of RS-1 were prepared from the same pool of normal RS-1. Peripheral well 1 contains $0.5 \mathrm{mg}$ of original material; other wells contain approximately $0.5 \mathrm{mg}$ of various fractions.

nary mucoprotein (3), Anderson-Maclagan urinary material (8), and Di Ferrante-Popenoe (4) and Maxfield (7) mucosubstance all gave the typical "reaction of identity" with normal R-1 material (Figure 2). CTAB preparations consistently gave a broad zone of precipitin reaction in gels as illustrated in Figure 2. Utilizing lyophilized samples of the above materials, the proportions for optimal antigen-antibody reaction were essentially the same for R-1, Tamm and Horsfall, and Maxfield substances. Approximately 30 per cent more Anderson-Maclagan material was required to give equivalent precipitation.

Rabbit antihuman serum protein antibodies gave no precipitation in tubes or gel with $\mathrm{R}-1$, Tamm and Horsfall or Maxfield substances. A distinct precipitation in tubes and gel was obtained with this antibody and with Anderson-Maclagan material (Figure 3).

The normal RS-1 (nonultrafiltrable, veronalsoluble) urinary preparations gave two distinct zones of precipitation with the anti-R-1 antibody. Fractionation of RS-1 by Cohn method 10 into three primary fractions-RS-1A (Cohn I, II, III), RS-1B (Cohn IV, V), and RS-1C (Cohn VI) (2) -resulted in multiple zones of precipitation with the anti-R-1 antibody and each preparation (Figure 4). When RS-1 material was brought to $\mathrm{pH} 3$ with dilute acetic acid, both the precipitate and supernate gave multiple precipitin zones with the anti-R-1 antibody. CTAB treatment of a solution of RS-1 solids by the method of Maxfield (7) gave multiple zones of precipitation for the supernate and a single line with the precipitate when 
tested against anti-R-1 antibody. RS-1 fractions of urine from patients with renal calculi, pyelonephritis, cancer and other inflammatory or degenerative diseases consistently gave precipitin reactions with anti-R-1 antibody (Figure 5).

Rabbit antihuman serum antibody gave multiple precipitation zones with the RS-1 preparations. Absorption of RS-1 with rabbit antihuman serum antibody did not alter the serological response to rabbit anti-R-1 antibody.

The nondialyzable ultrafiltrable solids, UF-O, of urine (13) contained no detectable $\mathrm{R}-1$ reactive substance even at concentrations up to ten times those of optimal concentration for R-1 solids. A precipitate obtained from a solution of UF-O with CTAB failed to give an antigen-antibody precipita- tion with the anti-R-1 antibody in tubes or gel diffusion.

Presence of $R-1$ in renal and other tissues. The renal tissue preparations consistently gave a positive precipitin reaction with the rabbit anti-R-1 antibody. The concentration of antigen in the various tissue preparations decreased in the following order: cortex, medulla, pelvis denuded of epithelium, whole pelvis, and epithelium stripped from pelvis. The epithelium required approximately four times the tissue concentration of cortex to give comparable precipitation reactions with the anti-R-1 antibody.

The cortex and medulla commonly gave two zones of precipitation with the antibody; the pelvis and epithelium gave single zones of precipi-

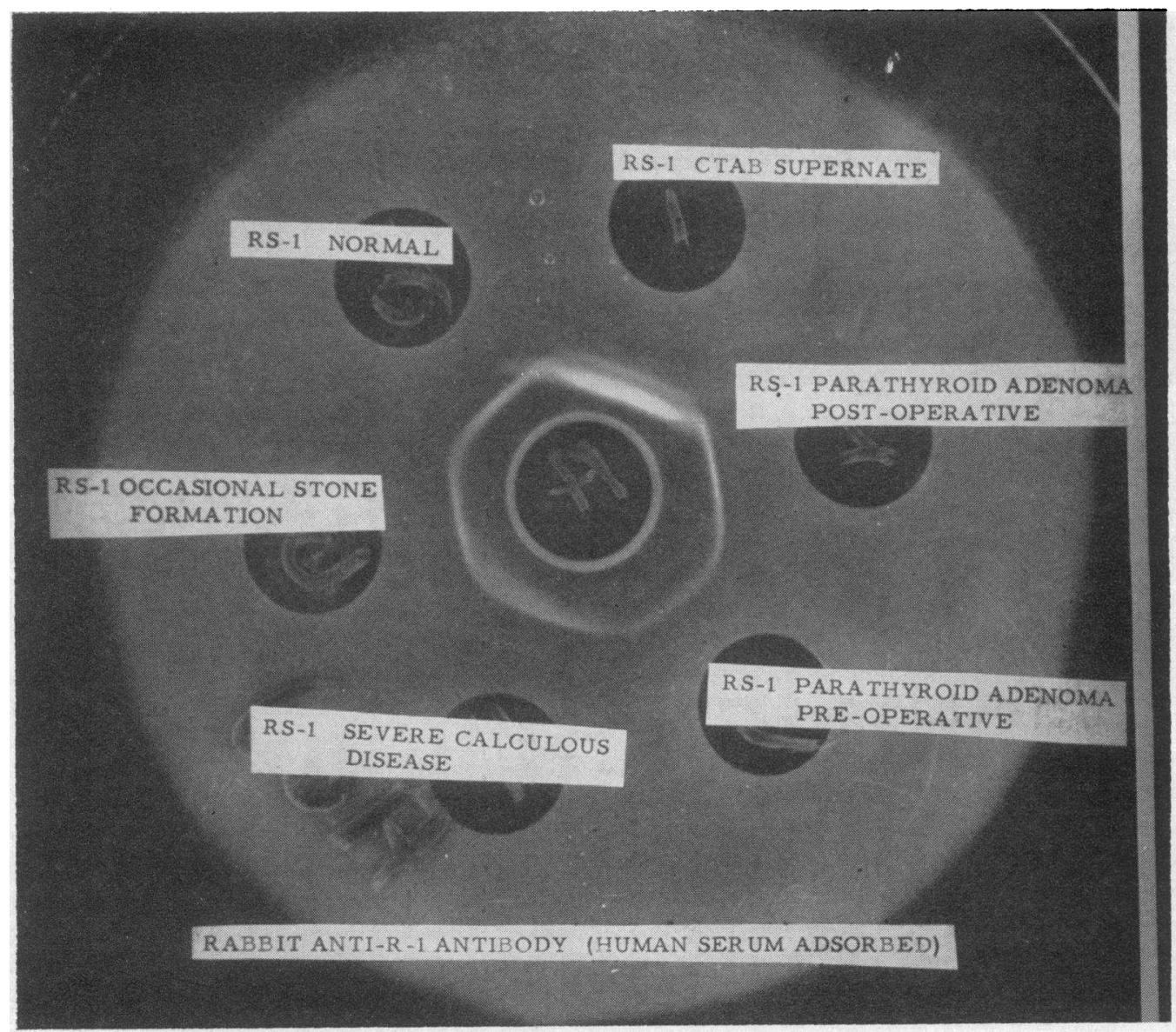

Fig. 5. Precipitin Reactions obtained against anti-R-1 antibody with noRmal RS-1 ANd RS-1 URINARY Fractions from patients with Renal Calculi. Peripheral well 1 contains lyophilized supernate from CTAB treatment of a solution of RS-1. The RS-1 preparations in other peripheral wells are from the same patients as R-1 preparations in Figure 1. Each peripheral well contains approximately $1 \mathrm{mg}$ of test substance. 


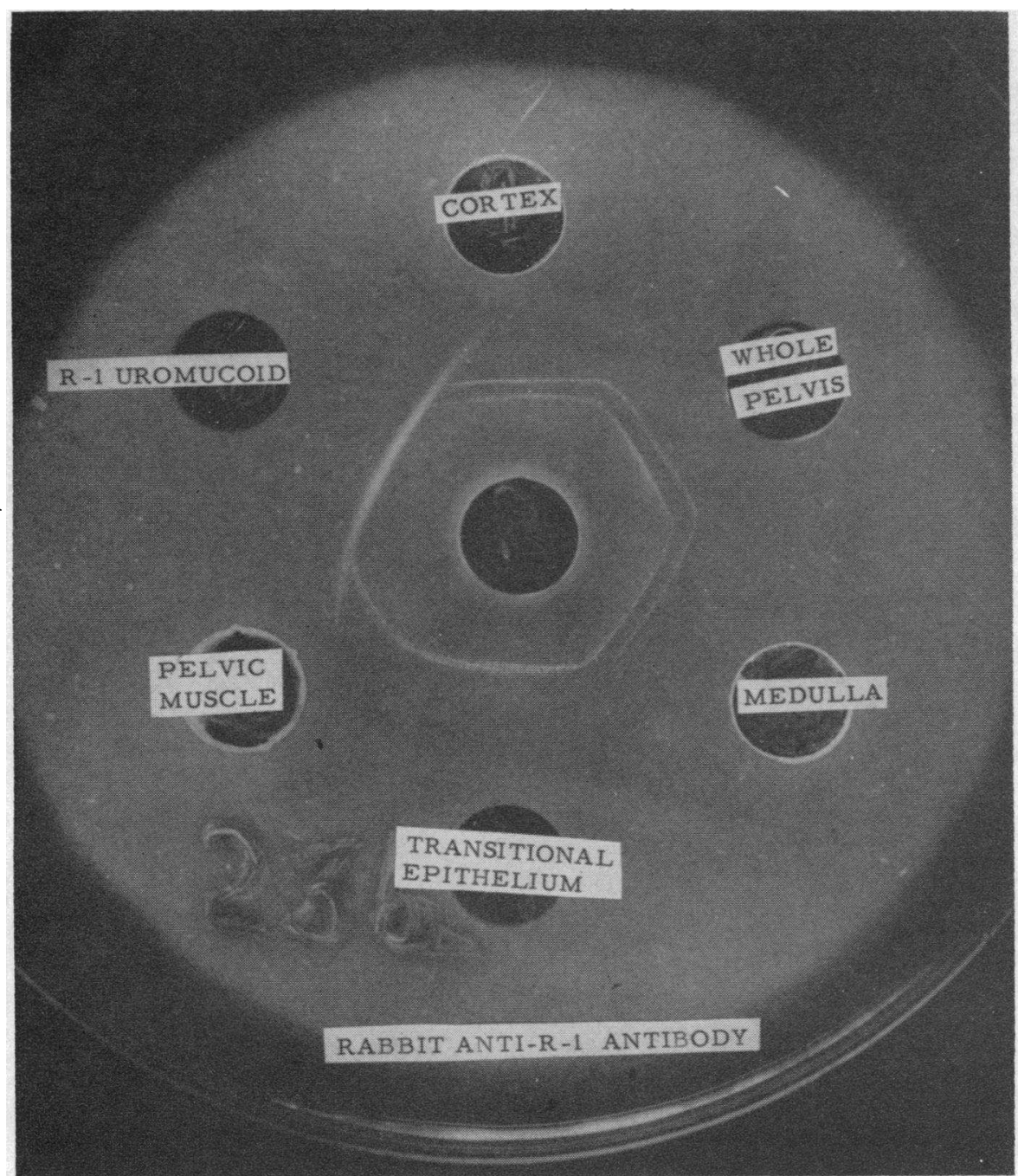

Fig. 6. Precipitin Reactions of URINARy tissues and NORMal R-1 muCoId against ANTI-R-1 ANTIBODY. The tissue preparations contain approximately 300 to $500 \mathrm{mg}$ of suspended solids per well, compared with $1 \mathrm{mg}$ of R-1 substance in well 6 . Tube titration of equivalent zone of precipitin reactions of these tissue preparations is not possible because of the opacity of the solutions. Ultracentrifugation to clarity removes all but traces of the anti-R-1 precipitable substance.

tation in gel. Precipitation reactions in gel were obtained from all preparations of skin and subcutaneous fat, lumbodorsal fascia, and striated muscle. These various tissue preparations gave a "reaction of identity" with each other, but the R-1 substance usually gave a distinct spur with the tissue preparations (Figures 6 and 7). Such spur formation has usually been interpreted as a "reaction of partial identity" (12), and persisted through tenfold dilutions of either antibody or antigens. With progressive dilutions of antiserum the spur formation disappeared before complete loss of the tissue precipitin reaction, thus giving the appearance of "reactions of identity" between R-1 and tissue antigens. A similar response was noted in anti-R-1 antibodies of low titer from animals which had not received challenge doses of antigens in 8 months. The spur formation promptly reappeared when the antibody titer was boosted by a challenge dose of R-1 without adjuvant.

Absorption of anti-R-1 antibody with increas- 
ing quantities of renal tissue slurry completely absorbed the serological response of the antibody to all of the various tissue slurries. Antiserum thus absorbed continued to give a serological response to urinary $\mathrm{R}-1$ and a single precipitin reaction of identity to urinary RS-1 solids. The less rapidly diffusible of the two zones of precipitin reaction, uniformly present with RS-1 solids diffused against untreated antibody, was absent in all preparations of tissue-absorbed antibody which failed to give a serological response to tissue. It was not possible to remove all serological reactivity of the antibody to R-1 solids by absorption with renal tissue slurries even when the wet weight of tissue $(1,000 \mathrm{mg})$ exceeded the $\gamma$-globu- lin content of the antibody preparation $(10 \mathrm{mg})$ by 100 -fold.

On the other hand, the absorption of anti-R-1 antibody with increasing quantities of R-1 resulted in complete loss of serological response of the antiserum to all tissues and to all R-1 and RS-1 preparations. Attempts to absorb the R-1 reactive component of the antiserum by titration with R-1 without absorption of the tissue and RS-1 reactive components were uniformly unsuccessful.

This suggests that R-1 evokes antibody formation to both the largest molecular form of R-1 and to the smaller chain lengths (half or quarter lengths or both). Freshly prepared R-1 precipi-

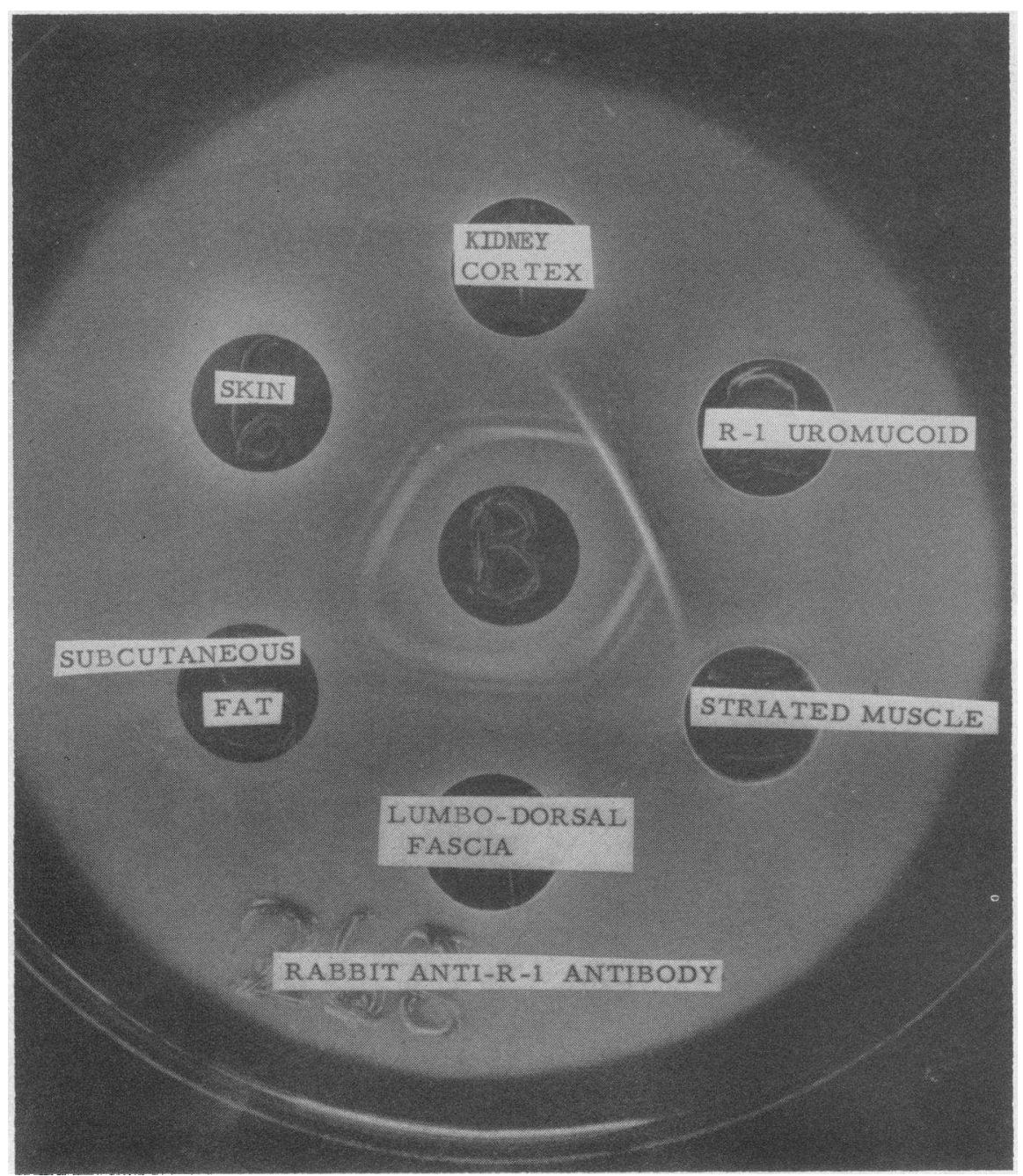

Fig. 7. Precipitin Reactions obtained from tissues of the abdominal wall against ANTI-R-1 ANTIBODY. 
tates all serologically reactive antibodies of anti$\mathrm{R}-1$ rabbit serum, although it contains predominantly the longer chain lengths. The tissues contain serologically reactive substance which completely precipitates only the antibodies to short chain lengths of R-1. On the basis of the spur formation between $\mathrm{R}-1$ and tissue serological reactions, the R-1 may be regarded as the "complete antigen," the tissue reactive substance as the "incomplete antigen."

The precipitin reaction of tissue extracts with anti-R-1 serum does not appear to be related to the use of Freund's adjuvant. Similar reactions were obtained with anti-R-1 antibodies produced without adjuvant. The Freund's adjuvant gave no precipitin reaction in tubes or gel with any of the anti-R-1 antibody preparations. Absorption of the anti-R-1 serum with Freund's adjuvant did not alter the precipitin reactions with the tissue extracts.

The various tissue extracts gave multiple zones of precipitation with rabbit antihuman serum antibodies. However, absorption (11) of the tissue extracts with up to five times the optimal concentration of antihuman serum antibody failed to prevent the subsequent response to anti-R-1 antibody. Normal rabbit serum gave no precipitin reaction with any of the tissue extracts, blood plasma, or urinary nondialyzable solids of human origin.

Absence of $R-1$ in various tissue fluids, bone and stone matrices. The anti-R-1 antibody failed to give any precipitation reaction in tubes or gel with human serum from 12 normal subjects or

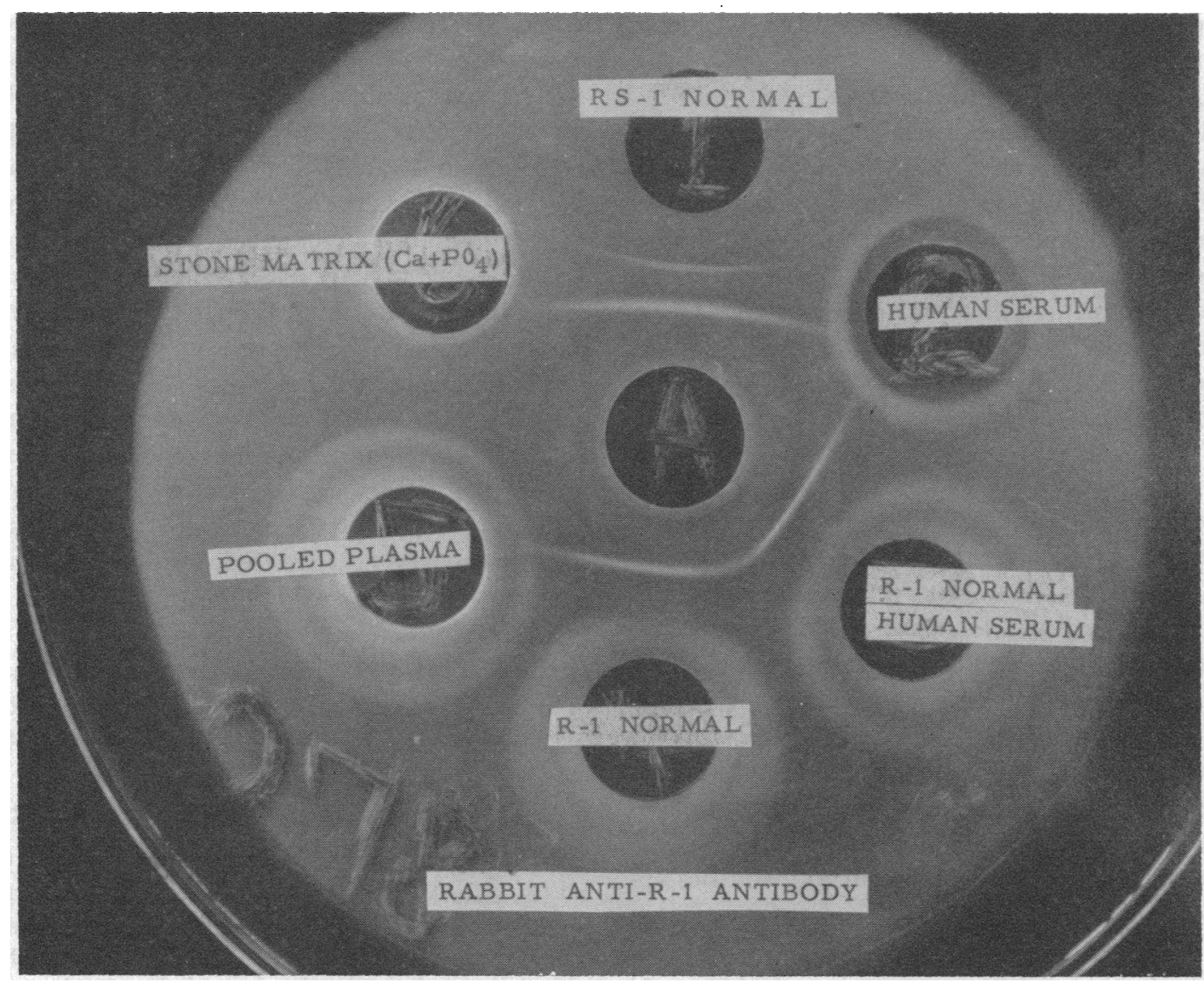

Fig. 8. Recovery of R-1 from nORMal human SERUm by anti-R-1 antibody. Well 1 contains $1 \mathrm{mg}$ of RS-1 solids and $0.5 \mathrm{mg}$ of R-1 in $0.4 \mathrm{ml}$ distilled water. Well 2 contains $0.4 \mathrm{ml}$ of fresh normal serum. Well 3 contains $0.5 \mathrm{mg}$ of $\mathrm{R}-1$ in $0.4 \mathrm{ml}$ of normal serum. Well 4 contains $0.5 \mathrm{mg}$ of $\mathrm{R}-1$ in $0.4 \mathrm{ml}$ of distilled water. Well 5 contains $0.4 \mathrm{ml}$ of pooled normal plasma from 10 subjects. Well 6 contains $2 \mathrm{mg}$ of whole freshly prepared renal calcigerous calculus matrix in $0.4 \mathrm{ml}$ of distilled water. 
with the serum of the patients from whom the above renal tissue was obtained. Serum from six patients with severe calculous disease and from ten patients with severe debilitating disease, terminal metastatic cancer, hepatic cirrhosis, and recent major surgical procedures, also failed to give precipitation reactions with anti-R-1 antibody. Lyophilized R-1 suspended in fresh normal serum for 24 hours at $3^{\circ} \mathrm{C}$ or incubated with normal serum at $56^{\circ} \mathrm{C}$ for 1 hour subsequently gave precipitin reactions with anti-R-1 antibody, and was detectable in dilutions of $1 \mathrm{mg} \mathrm{R}-1$ in $23 \mathrm{ml}$ of plasma (Figure 8). These suspensions of R-1 also gave a "reaction of identity" with untreated R-1 antigen in the gel diffusion plates. Failure of rabbit antihuman serum protein antibodies to give a precipitin reaction with R-1 (Figure 3 ) is additional evidence that R-1 substance is not present in detectable quantities in human serum.

No evidence of precipitation with anti-R-1 antibody was obtained from the several preparations of erythrocyte membranes, viral hemagglutination inhibitory mucoprotein of human saliva, bone matrix, matrices of urinary calculi (Figure 8 ), or human seminal plasma. Concentration of these substances was tested over a range of approximately 0.1 to 10 times the optimal concentration of R-1 for the preparations of anti-R-1 antibody.

\section{DISCUSSION}

Tamm and Horsfall (3) precipitated mucoprotein(s) from normal urine by addition of $\mathrm{NaCl}$ to $0.58 \mathrm{M}$. The recovery was $25 \mathrm{mg}$ per L, of which $12 \mathrm{mg}$ was soluble in $0.025 \mathrm{M}$ phosphate buffer ( $\mathrm{pH}$ 6.8) and was found to contain all of the viral hemagglutination inhibitory material. Utilizing a similar technique, Odin (14) recovered $13 \mathrm{mg}$ of viral inhibitory mucoprotein, which contained 8 per cent sialic acid per L of urine. In the earlier reports from this laboratory (1), the substance R-1 was found to occur in quantities approximately eight times that reported by Tamm and Horsfall for viral inhibitory urinary mucoprotein and to contain a quantity of sialic acid varying from 9 to less than 1 per cent, as measured by the diphenylamine reaction. Since Tamm and Horsfall mucoprotein recovered by $\mathrm{NaCl}$ pre- cipitation in this laboratory did not lose sialic acid by subsequent dialysis against distilled water or by the ultrafiltration technique, it was assumed that the sialic acid-free portion of R-1 represented a previously undescribed urinary mucoid. This material was demonstrated not to inhibit the hemagglutinating activity of influenza viruses. ${ }^{1}$ The term "uromucoid" was therefore applied to this component of the R-1 fraction of normal urine. The demonstration of complete antigenic identity between R-1 uromucoid and Tamm and Horsfall mucoprotein suggests that uromucoid may be Tamm and Horsfall material that has lost its complement of sialic acid. It has been demonstrated (3) that treatment of Tamm and Horsfall mucoprotein with an extract of Vibrio cholerae causes loss of inhibitory activity but not of immunological precipitability.

The differences in recovery are apparently accounted for by incomplete precipitation; unlyophilized Tamm and Horsfall material had a solubility in $0.58 \mathrm{M} \mathrm{NaCl}$ of $85 \mathrm{mg}$ per $\mathrm{L}$. Since it has been demonstrated that neither lyophilization, dialysis nor ultrafiltration per se will remove sialic acid from the Tamm and Horsfall mucoprotein and that the various preparations of Tamm and Horsfall urinary mucoprotein contain varying amounts of sialic acid, one may assume either that uromucoid has never had 8 per cent sialic acid or that the dialysis of whole urine removes an inhibitor of a neuraminidase which then releases the sialic acid prior to ultrafiltration. Collection and dialysis of urine in the presence of ethylenediamine tetraacetic acid, which should inhibit neuraminidase (15), did not yield an R-1 fraction with a greater sialic acid content than an untreated control. Sialic acid in R-1 was no different in an immediately dialyzed urine as compared with a control which stood 3 days at $4^{\circ} \mathrm{C}$ before dialysis.

Variation in particle size of Tamm and Horsfall urinary mucoprotein, both in the native state and

\footnotetext{
1 Dr. Maurice Hilleman, Merck Institute for Therapeutic Research, reported that neither of two samples submitted, having less than 1 per cent sialic acid, inhibited hemagglutination by Asian influenza virus (Jap. 305-57), Influenza A (Netherlands) or Influenza B (Great Lakes strain). The limited solubility of this material in physiological saline tended to make the results valid for low concentration only.
} 
by mild alterations in physicochemical environment, has been demonstrated. Porter and Tamm (16) examined samples of unlyophilized material by electron microscopy and found the flexible filaments to vary greatly in length. The molecules had a width of about $100 \AA$, an average length of about $25,000 \AA$, and a nodose structure with high points spaced at about $110 \AA$. On the basis of ultracentrifugal and diffusion data, Tamm, Bugher and Horsfall (17) assigned a molecular weight of $7 \times 10^{6}$ as the mean particle size of these filaments. Such relatively mild treatment as heating the mucoprotein at $70^{\circ} \mathrm{C}$ for $30 \mathrm{~min}$ utes in phosphate buffer at $\mathrm{pH} 6.8$ resulted in splitting of the molecule with emergence of a smaller component on ultracentrifugation, a reduction in molecular asymmetry by viscosimetry, and a reduction in electrophoretic mobility.

Maxfield (18) has demonstrated that Tamm and Horsfall mucoprotein of molecular weight $7 \times 10^{6}$ may be separated into units of halflength (mol wt $\left.3.5 \times 10^{6}\right)$ and quarter units $(\mathrm{mol}$ wt $\left.1.7 \times 10^{6}\right)$. The half-length units were prepared from Tamm and Horsfall mucoprotein by treatment with CTAB and these units were identical with the virus inhibitory mucoprotein of $\mathrm{Di}$ Ferrante and Rich (6). The quarter-length molecules were prepared by prolonged treatment of Tamm and Hosfall mucoprotein with CTAB followed by alcohol. Maxfield suggests that the Tamm and Horsfall material represents the native form of this material in normal urine. The normal urine is presumed to contain an inhibitor which protects the bonds that are broken by alcohol to give the subfractions of Tamm and Horsfall mucoprotein.

The demonstration of broad zones of precipitation in gel when CT.AB precipitates of urinary fractions are diffused against anti-R-1 antibody is consistent with the fragmentation of Tamm and Horsfall mucoprotein. The presence of multiple precipitin zones in all Cohn fractions of RS-1 subjected to anti-R-1 antibody is consistent with Maxfield's observation that dialysis of urine permits ethanol to disrupt certain bonds of Tamm and Horsfall mucoprotein and that small quantities of ethanol greatly increase the solubility of these fragments in $0.58 \mathrm{M}$ sodium chloride solutions.

The consistent presence of two zones of precipi- tation in gel when RS-1 solids are matched with anti-R-1 antibody suggests the presence of more soluble (presumably smaller) components of R-1 in normal urine. The quantity of these may be relatively large since, by planimetric estimate from electrophoretic experiments, the mean concentration of the ten identifiable gradients of RS-1 solids may range between 2 and $19 \mathrm{mg}$ per 24 hours (19). Grant (20) and Vaerman and Heremans (21) found immunoelectrophoretic evidence for at least two forms of Tamm and Horsfall mucoprotein in urine. Grant also noted a "reaction of identity" between urinary mucoproteins precipitated by $0.58 \mathrm{M} \mathrm{NaCl}$, cetyltrimethylammonium bromide and benzoic acid.

The serological response of tissue to anti-R-1 antiserum is probably not due to contamination of R-1 with an antigenically competent molecule of tissue origin. If such a contaminant were present, the serological response of the antibody to tissue should be separable from the response to $\mathrm{R}-1$ by progressive titration of the antiserum with $\mathrm{R}-1$. The tissue contaminant should also have been detectable by ultracentrifugation or electrophoresis of the R-1 preparations.

The demonstration of substances in renal parenchyma, renal pelvis, skin, fat, fascia, and striated muscle which give "reactions of partial identity" with the anti-R-1 antibody suggests the presence of molecules which contain in part the same antigenic determinants as the R-1 molecule. The chemical analysis and ubiquity with which these occur in tissues suggest that they may be components of the "ground substance" in the concept of Gersh and Catchpole (22). The R-1 substance in urine may be derived entirely from the tissues of the urinary system and, since it has been clearly identified only in urine, it may be a secretory product of the renal tubular cells. If this material is transported to the kidneys by the blood plasma, the concentration in plasma is either too small to be detectable by our methods or the antigenically reactive groups are effectively blocked in some manner during the plasma transport. If one accepts the value of $700 \mathrm{ml}$ per minute for renal plasma flow and postulates the complete clearance of R-1 by the kidneys, then a minimal concentration of $1 \mathrm{mg}$ in $11,200 \mathrm{ml}$ of plasma could account for the daily excretion of $90 \mathrm{mg}$ of R-1. Our 
methods will not detect plasma concentrations of $\mathrm{R}-1$ below $1 \mathrm{mg}$ in $23 \mathrm{ml}$.

\section{SUM MARY}

The R-1 fraction of normal urine has been demonstrated to be highly antigenic for rabbits, to be capable of producing anaphylaxis, and to retain its antigenic properties under a variety of alterations in physicochemical environment.

Reactions of immunological identity have been established between the R-1 uromucoid and the urinary mucoproteins described by Tamm and Horsfall, Di Ferrante and Popenoe, and by Maxfield. The Anderson and Maclagan benzoic acidadsorbable material of urine contains both R-1 substance and appreciable quantities of RS-1 solids derived from blood plasma.

Two zones of precipitation occur in gel diffusion reactions between homogenous anti-R-1 antibody and the nonultrafiltrable, veronal-soluble RS-1 components of urine, these zones becoming more numerous after treatment of RS-1 solids with cetyltrimethylammonium bromide, dilute ethanol, or acetic acid to $\mathrm{pH} 3$. This is interpreted as additional evidence that R-1 uromucoid occurs in two or more physical forms in normal urine, the variations being largely a matter of length of the molecule and solubility in various solutions.

An immunological reaction of partial identity has been demonstrated between the human urinary R-1 substance and tissue extracts of human renal parenchyma, renal pelvis, skin, fat, lumbodorsal fascia, and striated muscle from the abdominal wall.

No evidence could be obtained for the presence of substances antigenically reactive to anti-R-1 antibody in the following preparations: matrices from a variety of renal calculi, human blood plasma in health and various disease states, erythrocyte membranes, human saliva, matrix from fetal bone, human seminal plasma, or the nondialyzable ultrafiltrable solids (UF-O) of normal urine.

It is suggested that a substance related to the material found in urinary fraction R-1 may be a component of the "ground substance" of various tissues, but is not a "calcifiable" component of either bone matrix or urinary calculi. The R-1 uromucoid as recovered in urine has not been clearly identified in any body fluid or tissue other than urine.

\section{ACKNOWLEDGMENT}

The authors wish to acknowledge the technical assistance of Mrs. B. J. Masten and Mrs. Phyllis Tilley.

\section{REFERENCES}

1. Boyce, W. H., King, J. S., Jr., Little, J. M., and Artom, C. Total nondialyzable solids (TNDS) in human urine. II. A method for reproducible fractionation. J. clin. Invest. 1958, 37, 1658.

2. King, J. S., Jr., Little, J. M., Boyce, W. H., and Artom, C. Total nondialyzable solids (TNDS) in human urine. III. A method for subfractionation of RS-1 solids. J. clin. Invest. 1959, 38, 1520.

3. Tamm, I., and Horsfall, F. L., Jr. Mucoprotein derived from human urine which reacts with influenza, mumps, and Newcastle disease viruses. J. exp. Med. 1952, 95, 71.

4. Di Ferrante, N., and Popenoe, E. A. Hexosaminecontaining proteins co-precipitated with urinary mucopolysaccharides (abstract). Scand. J. clin. Lab. Invest. 1958, 10, suppl. 31, 268.

5. Gardell, S. Separation on Dowex 50 ion-exchange resin of glucosamine and galactosamine, and their quantitative determination. Acta chem. scand. 1953, 7, 207.

6. Di Ferrante, N., and Rich, C. The determination of acid aminopolysaccharide in urine. J. Lab. clin. Med. 1956, 48, 491.

7. Maxfield, M. Physicochemical study in salt solution of a urinary mucoprotein with virus-inhibiting activity. Arch. Biochem. 1959, 85, 382.

8. Anderson, A. J., and Maclagan, N. F. The isolation and estimation of urinary mucoproteins. Biochem. J. 1955, 59, 638.

9. Marmion, B. P., Curtain, C. C., and Pye, J. The effect of human bronchial secretions (sputum) on the haemagglutinin and infectivity of influenza virus. Aust. J. exp. Biol. med. Sci. 1953, 31, 505.

10. King, J. S., Jr., and Boyce, W. H. Analysis of renal calculous matrix compared with some other matrix materials and with uromucoid. Arch. Biochem. 1959, 82, 455.

11. Dean, H. R., and Webb, R. A. The influence of optimal proportions of antigen and antibody in the serum precipitation reaction. J. Path. Bact. 1926, 29, 473.

12. Ouchterlony, O. Diffusion-in-gel methods for immunological analysis in Progress in Allergy, $\mathrm{P}$. Kallos, Ed. Basel, S. Karger, 1958, vol. 5, p. 1.

13. King, J. S., Jr., and Boyce, W. H. Total nondialyzable solids (TNDS) in human urine. V. Subfractionation of the ultrafiltrate (UF-O) fraction. J. clin. Invest. 1959, 38, 1927.

14. Odin, L. Carbohydrate residue of a urine mucoprotein inhibiting influenza virus haemagglutination. Nature (Lond.) 1952, 170, 663. 
15. Warren, L., and Spearing, C. W. Mammalian sialidase (neuraminidase). Biochem. biophys. Res. Com. 1960, 3, 489.

16. Porter, K. R., and Tamm, I. Direct visualization of a mucoprotein component of urine. J. biol. Chem. 1955, 212, 135.

17. Tamm, I., Bugher, J. C., and Horsfall, F. L., Jr. Ultracentrifugation studies of a urinary mucoprotein which reacts with various viruses. J. biol. Chem. 1955, 212, 125.

18. Maxfield, M. Fractionation of the urinary mucoprotein of Tamm and Horsfall. Arch. Biochem. 1960, 89, 281.
19. Boyce, W. H., and King, J. S., Jr. Total nondialyzable solids (TNDS) in human urine. IV. Electrophoretic properties of RS-1 subfraction. J. clin. Invest. 1959, 38, 1525.

20. Grant, G. H. The proteins of normal urine. J. clin. Path. 1957, 10, 360.

21. Vaerman, J. P., and Heremans, J. F. Etude immuno-électrophorétique de l'uromucoïde. Experientia (Basel) 1959, 15, 226.

22. Gersh, I., and Catchpole, H. R. The nature of ground substance of connective tissue. Perspec. Biol. Med. 1960, 3, 282. 